\title{
Performance of dairy calves raised under two breeding systems
}

\section{Desempenho de bezerras leiteiras submetidas a dois sistemas de criação}

\author{
Reinaldo Henrique Borger ${ }^{1}$; Adriana de Souza Martins ${ }^{2 *}$; \\ Shivelly Los Galetto ${ }^{3}$; Victor Breno Pedrosa ${ }^{2}$; \\ Raquel Abdallah da Rocha Oliveira²; Luciana da Silva Leal ${ }^{2}$
}

\begin{abstract}
Increasing concern about some animal production systems has placed considerable value on humanitarian breeding systems, aimed at ensuring animal welfare and comfort. Raising calves is one of the most important stages in a milk production system. This study aimed to evaluate and compare the performance of Holstein dairy calves raised by two farming systems: conventional individual (CI) and collective with automatic calf feeder (CACF). Fourteen, 15-day-old Holstein dairy calves having an average initial body weight of $40 \mathrm{~kg}$, were used. The animals were distributed in a completely randomized design with seven animals per treatment. The variables evaluated were the milk and feed intake, body weight, hip height, thoracic circumference and daily weight gain. The average milk intake was lower in the CACF $\left(3.5 \mathrm{~L}_{\text {animal }}{ }^{-1} \mathrm{day}^{-1}\right)$ than CI $\left(5.1 \mathrm{~L} \mathrm{animal}^{-1}\right.$ day $\left.^{-1}\right)$ system. However, the feed intake was higher in the CACF $\left(1.205 \mathrm{~kg}\right.$ animal $^{-1}$ day $\left.^{-1}\right)$ compared to CI $\left(0.910 \mathrm{~kg}\right.$ animal ${ }^{-1}$ day $\left.^{-1}\right)$ system. Body weight, thoracic circumference, hip height and daily weight gain were similar between the two systems. The CACF raised calves had a higher concentrate intake and lower milk intake than the calves raised under the CI system.
\end{abstract}

Key words: Calf feeder. Daily weight gain. Milk intake. Feed intake.

\section{Resumo}

Nas últimas décadas, a sociedade tem questionado alguns métodos de produção animal e, neste sentido, tem sido valorizado os sistemas de criação humanitária de animais, visando o bem-estar e conforto animal. Considerando que a criação de bezerras constitui uma das fases mais importantes em um sistema de produção de leite, objetivou-se avaliar e comparar o desempenho de bezerras leiteiras da raça Holandesa submetidas aos sistemas de criação individual e coletivo com alimentador automático. Foram utilizadas 14 bezerras da raça Holandesa, com 15 dias de idade e peso corporal inicial médio de $40 \mathrm{~kg}$. Os animais foram distribuídos em delineamento inteiramente casualizado, em dois sistemas de criação: Criação convencional individual (CCI); Criação coletiva com alimentador automático (CCAA), sendo sete animais por tratamento. Avaliaram-se o consumo de leite e de ração, peso corporal, altura de garupa, perímetro torácico e o ganho de peso médio diário. O consumo médio de leite foi menor no sistema CCAA (3,5 $\mathrm{L}$ animal $^{-1}$ dia $\left.^{-1}\right)$ em relação ao CCI $\left(5,1 \mathrm{~L}\right.$ animal ${ }^{-1}$ dia $\left.^{-1}\right)$, porém a ingestão de ração foi maior no sistema CCAA $\left(1,205 \mathrm{~kg}_{\text {animal }}{ }^{-1} \mathrm{dia}^{-1}\right)$ comparado ao sistema CCI $\left(0,910 \mathrm{~kg}\right.$ animal ${ }^{-1}$ dia $\left.^{-1}\right)$. As variáveis peso corporal, perímetro torácico, altura de garupa e ganho de peso diário dos bezerros foram semelhantes entre os sistemas. Bezerras criadas coletivamente com o uso de alimentador automático apresentam maior consumo de concentrado e menor consumo de leite.

Palavras-chave: Alimentador automático para bezerros. Consumo de leite. Consumo de ração. ganho de peso médio diário.

${ }^{1}$ Zootecnista, Universidade Estadual de Ponta Grossa, UEPG, Ponta Grossa, PR, Brasil. E-mail: rei_borger@hotmail.com

2 Profs. Drs., Departamento de Zootecnia, UEPG, Ponta Grossa, PR, Brasil. E-mail: dri261@yahoo.com.br; vbpedrosa@yahoo. com.br; raroliveira@uepg.br; lu_s_leal@yahoo.com.br

${ }^{3}$ Discente, Curso de Doutorado do Programa de Pós-Graduação em Agronomia, UEPG, Ponta Grossa, PR, Brasil. E-mail: shivelly_galetto@hotmail.com

* Author for correspondence 


\section{Introduction}

Brazil is the fifth major milk producing country worldwide. In 2014, Brazil produced 35.17 billion liters of milk (IBGE, 2015). In this context, proper nutrition, the health of the herd, management techniques used, environmental conditions and animal welfare become key factors to achieve high yields and ensure the viability of dairy farming.

The farming of dairy calves is one of the most important components in a dairy production system. Besides becoming the replacement females of the herd, the sale of calves and heifers can contribute significantly to income (CUNHA; MARTUSCELLO, 2009). However, some precautions are necessary to succeed in raising dairy cattle. The syndesmochorial placenta of bovines prevents the transfer of antibodies to calves. Thus, the newborns are susceptible to infection and have low resistance to diseases and pests. Management practices, such as cleaning of the birthplace, colostrum intake in the first $12 \mathrm{~h}$ and disinfection of the umbilicus are crucial to ensure successful breeding of calves (SANTOS et al., 2010).

According to Ferreira et al. (2013), diseases such as diarrhea, pneumonia and metabolic disorders, frequently affect the development of the calf digestive tract and there is an association between the physiological development of the digestive tract and body weight at weaning. Thus, an efficient system of breeding calves on dairy farms should aim to produce healthy, fertile and developed females, managed in a clean and comfortable environment. Currently, there are various farming systems for breeding calves and depending on the system used, animal performance can be affected by several factors, such as nutrition, health, genetics and management (OLIVEIRA et al., 2014).

The most widespread Brazilian system of housing dairy calves is based on single pens. This housing has advantages, such as a decrease in disease transmission, individual clinical monitoring and no competition for feed among the calves (VIEIRA et al., 2010). Conversely, one disadvantage of this system is less movement and socialization of the animals. Moreover, there is greater demand for skilled labor that respects feed supply times in adequate amounts (OLIVEIRA et al., 2014).

Collective breeding of calves with automatic feed systems (calf feeder) is being increasingly used in dairy farms in Brazil because it facilitates the management, reduces feed waste and provides better distribution in the individual feeding of animals during a 24-h period (FUJIWARA et al., 2014; SVENSSON; LIBERG, 2006).

The calf feeder consists of a device that controls the supply of milk and concentrates, feeding up to 25 individual animals. In this system, milk and concentrate are gradually released on every visit to the station (PASSILLÉ et al., 2011). Another advantage associated with this system is social life, because dairy calves naturally live in groups, and therefore manifests their natural characteristics (FUJIWARA et al., 2014; VIEIRA et al., 2012). However, some studies have reported greater difficulties in sanitary control and increased competition for feed and milk among animals undergoing this breeding system compared to the CI system (HEPOLA, 2003; SVENSSON; LIBERG, 2006).

In recent decades, society has questioned some animal production systems, with particular importance placed on humanitarian livestock systems for the welfare and comfort of animals (FERREIRA et al., 2013). Therefore, studies that compare the performance of dairy calves under individual and collective farming systems are essential to meet the market requirements and management practice demands, aimed at improving the welfare of animals intended for food production.

This investigation aimed to evaluate and compare the performance of Holstein dairy calves raised under an individual versus a collective farming system with automatic calf feeder. 


\section{Material and Methods}

The experiment was carried out from February to June 2013 on Agropecuária Tjemara farm, located in Carambeí city, Paraná State, Brazil. According to Köppen classification, the climate of the region is $C f b$, experiencing cool summers and frequent frost occurrence, with average minimum and maximum temperatures of 13 and $24^{\circ} \mathrm{C}$, respectively.

Fourteen, 15-day-old Holstein calves with an initial average body weight of $40 \mathrm{~kg}$ were used. The calves were distributed in a completely randomized design into two farming systems: system 1 conventional individual (CI); system 2 - collective with automatic calf feeder (CACF), with seven animals per treatment. After birth, the calves from both systems received colostrum and were allocated to individual pens, with a covered and suspended floor, and containing a feeder and drinker, until they were 15 days old. At this age, the calves were treated according to the evaluated system (CI versus $\mathrm{CACF}$ ) until 60 days of age, and then weaned.

In the CI system, dairy calves were kept outdoors on a non-sloped floor, with grass and trees, and with a rope attached from their neck to the ground. The outdoor system exposed the animals to rain. Hence, the calves were often moved from one location to another to maintain a clean and comfortable shelter. Each animal was provided a supply of concentrate and milk (milk replacer). The concentrate was pre-weighed and given once a day, to provide approximately $20 \%$ remains. These were weighed daily to determine daily intake. The milk was given twice a day (at 09:00 and 16:00 h) as milk replacer (1:9 dilution). The amount offered varied according to age, provided to calves from 15 - 60 days of age, with up to $6,5 \mathrm{~L} /$ heifer being provided to 6.5 $\mathrm{L} /$ heifer, from 15 to 60 days. Water was offered ad libitum. The chemical composition of the milk replacer and concentrate are shown in Table 1.

Table 1. Chemical composition of concentrate and milk replacer.

\begin{tabular}{lcc}
\hline Parameter & Concentrate & Milk replacer \\
\hline Dry matter (\% original matter) & 90.00 & 91.00 \\
Mineral matter (\% DM) & 8.00 & 10.50 \\
Crude fiber (\% DM) & 6.00 & 0.05 \\
Crude protein (\% DM) & 19.00 & 19.50 \\
Ethereal extract (\% DM) & 2.50 & 14.50 \\
Lactose (\% DM) & - & 46.00 \\
\hline
\end{tabular}

(1) Pelleted commercial concentrate.

In the CACF system, calves were kept in a collective housing, partially covered shelter, with a cement floor, sawdust bedding, ad libitum access to water, and a two-unit calf feeder. The calf-feeder machine has a device that heats the milk, keeping it at the proper intake temperature for the calf. In this system, each calf receives an electronic transponder fixed on the earring, to control its individual daily consumption of milk and concentrate. The calf feeder has optical sensors that identify the animal by the transponder, providing the release of feed (milk and concentrate) in a pre-set amount, according to the age of the animal. The machine was programmed to avoid the release of larger portions of milk and concentrate when there is a surplus in the recipients. Thus, concentrate and milk amounts, as well as the available quantities, were recorded daily by an electronic sensor. The amount of concentrate programmed to be automatically provided at each visit of the animal to the calf feeder was $50 \mathrm{~g}$ while allowing full consumption of up to $2.5 \mathrm{~kg}$ day $^{-1}$. The daily volume of milk delivered to each calf 
was up to $7.5 \mathrm{~L}$, defined according to age, and up to $2.0 \mathrm{~L}$ per visit. The amount of milk available to the calves in the CACF system was higher than the CI system. This difference was implemented to avoid restriction of milk consumption in the CACF system because increased frequency of visits to the machine could result in a higher consumption. The concentrate and milk replacer composition used in both systems was equivalent.

The calves of both treatments were weaned at 60 days and transferred to paddocks with Tifton-85 grass (Cynodon sp.). The calves received concentrate (2.0 kg per day), mineral supplement ad libitum and corn silage. Calves remained in this system until 90 days of life.

The average consumption of milk and concentrate was assessed in two periods, namely 15-30 and 30-60 days, respectively. Additionally, the average total consumption of milk and concentrate was evaluated from 15-60-days of age, corresponding to the experimental period. The daily milk and concentrate intake was determined in the CI system by calculating the difference between the feed offered and the remains. In the CACF system, the intake was recorded electronically by the calf feeder.

The body weight, hip height and thoracic circumference of calves were recorded at 15, 30, 60 and 90 days of age. Morphometric measurements were performed according to Reis et al. (2004), in which the thoracic circumference was defined as perimeter measure just caudal to the scapula, passing through the sternum bone and spinal processes of the thoracic vertebrae. The hip height was measured from the ground to the ileum sacral tuberosity, on a flat surface. For body weight, a weighing tape for dairy cows was used, while a graduated measuring stick was used for height. The daily weight gain was evaluated in three periods, namely 15-30, 30-60 and 60-90 days, respectively.

The results were evaluated by variance analysis, according to the experimental design. When significant differences were observed $(\mathrm{P}<0.05)$, Tukey's test was performed at 5\% probability. All statistical analyses were done using SAS (SAS Institute Inc, Cary, NC, 2010).

\section{Results and Discussion}

Except for milk and concentrate consumption, there was no significant difference in body weight, hip height, thoracic circumference and average daily weight gain between the systems (Table 2). A higher intake of milk $(\mathrm{P}<0.05)$ was observed in calves housed in CI compared to CACF system. In contrast, the concentrate intake was lower in the CI $(\mathrm{P}<0.05)$ compared to CACF system.

During the suckling phase, the calf is considered a pre-ruminant because its digestive tract is still developing. At this stage, concentrate intake has a great effect on the rumen papillae development, transforming a pre-ruminant to a ruminant. Thus, the calf weaning can be early because it does not depend on a liquid diet. In this work, the increased concentrate intake associated with the CACF system was preferred over a reduction in milk intake. Probably, the greater frequency of visits to the calf feeder meant the calves did not ingest large amounts of milk, which was replaced by the concentrate. Moreover, in the CI system, where milk was only given twice daily, the eagerness to consume a liquid diet was relatively higher, reducing the concentrate intake. 
Table 2. Means values of milk and concentrate intakes, body weight, hip height, thoracic circumference and average daily weight gain according to farming systems.

\begin{tabular}{lrr}
\hline Parameter & \multicolumn{1}{c}{ CCI } & \multicolumn{1}{c}{ CCAA } \\
\hline Milk intake $^{(1)}\left(\mathrm{L} \mathrm{animal} \mathrm{day}^{-1}\right)$ & $5.13 \pm 0.07 \mathrm{a}$ & $3.52 \pm 0.28 \mathrm{~b}$ \\
Concentrate $i n t a k e^{(1)}\left(\mathrm{kg} \mathrm{animal} \mathrm{day}^{1}\right)$ & $0.91 \pm 0.21 \mathrm{~b}$ & $1.21 \pm 0.11 \mathrm{a}$ \\
Body weight $^{(2)}(\mathrm{kg})$ & $75.30 \pm 5.35 \mathrm{a}$ & $75.90 \pm 5.43 \mathrm{a}$ \\
Hip height $^{(2)}(\mathrm{m})$ & $0.88 \pm 0.02 \mathrm{a}$ & $0.89 \pm 0.03 \mathrm{a}$ \\
Thoracic circumference $^{(2)}(\mathrm{m})$ & $0.93 \pm 0.02 \mathrm{a}$ & $0.94 \pm 0.02 \mathrm{a}$ \\
Average daily weight gain $^{(2)}\left(\mathrm{kg} \mathrm{animal}^{-1}\right.$ day $\left.^{-1}\right)$ & $0.82 \pm 0.15 \mathrm{a}$ & $0.761 \pm 0.13 \mathrm{a}$ \\
\hline
\end{tabular}

Means followed by different letters in the same row, to differ by the Tukey's test, with $5 \%$ of probability. ( \pm ) Standard deviation. ${ }^{(1)}$ Mean values by $15-60$ days. ${ }^{(2)}$ Mean values by $15-90$ days. CI, conventional individual system; CACF, collective with automatic calf feeder system.

Khan et al. (2007) evaluated dairy Holstein calf housing systems in South Korea and observed that animals kept in a suckling CACF system for up to 63 days of life had a higher concentrate intake, weight gain and morphometric growth, and more advanced rumen development compared to the CI system. In this study, although average concentrate consumption was higher in the CACF system, this was not reflected in body weight and daily weight gain changes. Comparing different dairy calf systems, Raeth-Knight et al. (2009) reported higher growth of calves in suckling phase when milk intake was higher. However, this higher intake may reduce the solid feed intake, having a negative impact on rumen development (JASPER; WEARY, 2002).

The overall average daily weight gain of calves from 15-90 days old was 0.819 and $0.761 \mathrm{~kg}$ animal ${ }^{-1}$ day $^{-1}$ in the CI and CACF systems, respectively. Although there was no significant difference, the calves raised under the CI system showed 0.156 $\mathrm{kg}$ more weight gain compared to the CACF. This may have occurred due to the higher consumption of milk and, consequently, higher energy intake by calves raised under the CI system, because in the first weeks of life, the nutritional requirements are more readily met by a liquid diet.

The classic recommended milk intake in calves up to 60 days old is $4.0 \mathrm{~L}$ per day, offered twice daily (CHURCH, 1984; OLIVEIRA et al., 2009). However, more recent studies suggest providing relatively larger quantities of milk for calves (VON KEYSERLINGK; WEARY, 2012; OVERTON et al., 2013), because the increased consumption of nutrients during the first weeks have resulted in increased milk production in the first lactation. In this study, while consuming lower milk volume (3.52 $\mathrm{L}$ animal $^{-1}$ day $^{-1}$ ) in relation to the conventional recommendation for Holstein calves, the average daily weight gain, body weight and morphometric measurements were not adversely affected due to the low milk intake, probably due to the increased concentrate intake.

Evaluating the milk and concentrate consumptions at different times, i.e. from 15-30and 30-60-days-old, revealed that in both periods the results were similar to those presented on the total average consumption. Thus, animals housed in the CI system showed higher milk consumption and, consequently, lower concentrate consumption when compared to the CACF system (Table 3). This result may be related to the difference in milk supply frequency between the two systems. In the CI system, milk was only provided twice a day, which was less frequent than the CACF system. Thus, there was greater duration between suckling in calves raised under the CI system, which might have increased the milk intake. In the $\mathrm{CACF}$ system, the milk was released gradually, requiring more visits per day to achieve the total average consumption of $7.5 \mathrm{~L}$. 
Table 3. Mean of milk and concentrate intake by Holstein dairy calves according to farming systems.

\begin{tabular}{lcc}
\hline \multirow{2}{*}{ Período } & CI & CACF \\
\cline { 2 - 3 } & \multicolumn{2}{c}{ Milk intake $\left(\mathrm{L} \mathrm{animal}^{-1} \mathrm{day}^{-1}\right)$} \\
\hline 15-30 day old & $6.02 \pm 0.09 \mathrm{a}$ & $4.94 \pm 0.45 \mathrm{~b}$ \\
$30-60$ day old & $4.23 \pm 0.12 \mathrm{a}$ & $2.10 \pm 0.19 \mathrm{~b}$ \\
\hline & \multicolumn{2}{c}{ Concentrate intake $\left(\mathrm{kg} \mathrm{animal}^{-1}\right.$ day $\left.^{-1}\right)$} \\
\hline 15-30 day old & $0.376 \pm 0.24 \mathrm{~b}$ & $0.566 \pm 0.12 \mathrm{a}$ \\
$30-60$ day old & $1.444 \pm 0.21 \mathrm{~b}$ & $1.844 \pm 0.17 \mathrm{a}$ \\
\hline
\end{tabular}

Means followed by different letters in the same row, to differ by Tukey's test, with $5 \%$ of probability. ( \pm ) Standard deviation. CI, conventional individual system; CACF, collective with automatic calf feeder system.

Another factor is the difference in the milk storage time (milk replacer) after dilution. In the CI system, the dilution of the milk replacer was done just before each suckling time, but in the CACF system this was carried out twice a day (at 06:00 and at 18:00 h). Therefore, in the latter system, the milk was stored at the environmental temperature for 12 h. According to Hepola (2003), this storage may have contributed to microorganism proliferation (Lactobacillus sp.) and thus, milk fermentation, causing reduced consumption.

The higher consumption of concentrate in the CACF system is a result of a lower milk consumption. The concentrate consumption is directly responsible for nutrient supply to the calf and maintaining satisfactory rates of development. As such, it is one of the criteria that can be used for weaning when calves are over 30 days old (CUNHA; MARTUSCELLO, 2009). After 14 days of age, calves are capable of ingesting and metabolizing sufficient concentrate amounts that will contribute to their metabolic energy requirements (VAN AMBURGH, 2003).

In similar studies, Borderas et al. (2009) and Jensen (2006) also observed a decrease in milk consumption and an increase in concentrate consumption in calves raised in breeding systems that used an automatic calf feeder after 15 days of age. In calves up to 30 days old, the nutrients are supplied by milk. Therefore, at this stage, the high consumption of concentrate would not bring additional benefits to animal performance.
However, the larger the concentrate consumption, the greater the volatile fatty acids production (the main energy source for ruminants), which are responsible for transforming the digestive tract of the calf (SANTOS et al., 2010). Thus, the greater amount of milk replacer consumed, the longer it takes for the calf to become a ruminant, because when its nutritional needs are met by a liquid diet, there is usually no increase in the solid feed intake (VIEIRA et al., 2010).

An independent breeding system is economically viable to wean the calves as soon as possible, namely at about 45-60 days old. However, according to Oliveira et al. (2009), weaning itself only occurs when Holstein calves are consuming between 0.400 $0.600 \mathrm{~kg}$ of concentrate for the last three consecutive days. In contrast, according to Santos et al. (2010) for weaning at 60 days of age, providing 4.0-5.0 L of milk day ${ }^{-1}$ for the first 30 days of age, followed by 3.0-4.0 $\mathrm{L} \mathrm{day}^{-1}$ and 15 days thereafter $2.0 \mathrm{~L} \mathrm{day}^{-1}$, would be sufficient to wean the animals at this age, but it is important that calves are consuming 0.8-1.0 $\mathrm{kg}$ of concentrate.

It was observed that from 30-60 days of age, the average concentrate consumption in the $\mathrm{CACF}$ system was $22 \%$ higher $(\mathrm{P}<0.05)$ than the CI system, while milk consumption was $50 \%$ lower. In addition to the factors above-mentioned, the reduction in milk consumption may also be due to the form of milk replacer during $12 \mathrm{~h}$ storage in the automatic feeder. Despite automatic stirring, milk replacer sedimentation after preparation was more likely in 
the collective compared to the conventional system, leading to decreased palatability for calves.

Moreover, the greater movement of calves and mutual contact in the collective system may have contributed to increased concentrate consumption. Tapki (2007) suggested that breeding calves in collective systems allow greater physical activity than individual systems (which have less freedom of movement). This increases the nutrient requirements, favoring greater concentrate consumption, agreeing with the observations in this study.

Minimizing the use of milk or milk replacer in animal feed (because the nutritional requirements are met) may be associated with a higher profitability of activity, as long as the daily amount supplied or suckling period is not restricted such that it impairs the development of the calves (CUNHA; MARTUSCELLO, 2009).

There was no difference $(\mathrm{P}>0.05)$ in body weight, hip height and thoracic circumference between the farming systems in any evaluation period (Table 4). The body measurements can be influenced by breed, age, body condition, physiological state and genetics (HEINRICHS; HARGROVE, 1987). Heinrichs and Hargrove (1987) suggest that height reflects bone growth, while body weight reflects the growth of organs, muscles and adipose tissue. In this work, despite the differences between consumption of concentrate and milk in the systems, there was no change in body measurements of the calves, irrespective of the age ranges evaluated.

Table 4. Body weight, hip height and thoracic circumference of Holstein dairy calves to 15, 30, 60 and 90 days old according to farming systems.

\begin{tabular}{|c|c|c|}
\hline \multirow{2}{*}{ Period } & $\mathrm{CI}$ & CACF \\
\hline & \multicolumn{2}{|c|}{ Body weight $(\mathrm{kg})$} \\
\hline 15 days & $45.71 \pm 1.11 \mathrm{a}$ & $47.71 \pm 2.93 \mathrm{a}$ \\
\hline 30 days & $59.43 \pm 4.24 \mathrm{a}$ & $60.71 \pm 5.53 \mathrm{a}$ \\
\hline 60 days & $80.29 \pm 9.09 \mathrm{a}$ & $83.86 \pm 8.67 \mathrm{a}$ \\
\hline \multirow[t]{2}{*}{90 days } & $115.71 \pm 11.12 \mathrm{a}$ & $111.43 \pm 10.72 \mathrm{a}$ \\
\hline & \multicolumn{2}{|c|}{ Hip height (m) } \\
\hline 15 days & $0.80 \pm 0.04 \mathrm{a}$ & $0.82 \pm 0.03 \mathrm{a}$ \\
\hline 30 days & $0.84 \pm 0.03 \mathrm{a}$ & $0.84 \pm 0.02 \mathrm{a}$ \\
\hline 60 days & $0.90 \pm 0.03 \mathrm{a}$ & $0.91 \pm 0.03 \mathrm{a}$ \\
\hline \multirow[t]{2}{*}{90 days } & $0.98 \pm 0.03 \mathrm{a}$ & $0.97 \pm 0.04 \mathrm{a}$ \\
\hline & \multicolumn{2}{|c|}{ Thoracic circumference $(\mathrm{m})$} \\
\hline 15 days & $0.80 \pm 0.01 \mathrm{a}$ & $0.82 \pm 0.02 \mathrm{a}$ \\
\hline 30 days & $0.88 \pm 0.03 \mathrm{a}$ & $0.88 \pm 0.03 \mathrm{a}$ \\
\hline 60 days & $0.96 \pm 0.03 \mathrm{a}$ & $0.98 \pm 0.03 \mathrm{a}$ \\
\hline 90 days & $1.08 \pm 0.04 \mathrm{a}$ & $1.07 \pm 0.03 \mathrm{a}$ \\
\hline
\end{tabular}

Means followed by different letters in the same row, to differ by Tukey's test, with $5 \%$ of probability. ( \pm ) Standard deviation. CI, conventional individual system; CACF, collective with automatic calf feeder system.

Carvalho et al. (2003) reported that calves receiving large amounts of milk have higher gain in thoracic perimeter due to greater muscle and fat deposition, and have the largest vital organs due to greater space for growth, providing better development. As mentioned by Viégas (2010), the size of the heifer has a great influence on its morphology and can affect the future production capacity. In this regard, higher and longilinear animals usually have a larger body depth, which reflects desirably on the intake, breathing and circulatory capacity.

The average daily weight gain was not influenced $(\mathrm{P}<0.05)$ by the farming systems in the evaluated 
periods (Table 5). However, in contrast to the current study, Hepola (2003) found less weight gain in animals during the first 30 days of age under the CACF system. However, the milk and concentrate consumption verified by the authors was the same as that in this study. Yet, Tapki (2007) reported in their study that the animals under a CACF system showed higher average daily weight gain during 34-63 days of age, with higher consumption of concentrate when compared with the CI system.

Table 5. Average daily weight gain of Holstein dairy calves according to farming systems.

\begin{tabular}{lcc}
\hline \multirow{2}{*}{ Period } & CI & CACF \\
\cline { 2 - 3 } & \multicolumn{2}{c}{ Average daily weight gain $\left(\mathrm{kg} \mathrm{animal}^{-1}\right.$ day $\left.^{-1}\right)$} \\
\hline 15-30 days & $0.482 \pm 0.13 \mathrm{a}$ & $0.456 \pm 0.14 \mathrm{a}$ \\
30-60 days & $0.755 \pm 0.24 \mathrm{a}$ & $0.813 \pm 0.33 \mathrm{a}$ \\
$60-90$ days & $1.220 \pm 0.29 \mathrm{a}$ & $1.015 \pm 0.30 \mathrm{a}$ \\
\hline
\end{tabular}

Means followed by different letters in the same row, to differ by Tukey's test, with $5 \%$ of probability. ( \pm ) Standard deviation. CI, conventional individual system; CACF, collective with automatic calf feeder system.

The research of Vieira et al. (2010) corroborates the results observed in this investigation. They observed no difference in average daily weight gain among several farming systems evaluated (individual or collective). Weight gain is an important parameter to evaluate the body development of dairy calves. In an ideal management system, Cunha and Martuscello (2009) showed that the average weight gain during 30-60 days of age should be approximately $0.700 \mathrm{~kg}$, and during 60-90 days of age, it should $0.800 \mathrm{~kg}$. In this study, particularly at 60-90 days of age, the average daily weight gain in both treatments was above that recommended by Cunha and Martuscello (2009).

\section{Conclusions}

Calves raised under a collective with automatic calf feeder system have the same daily weight gain and body measurements as those under a CI system, despite differences in milk and concentrate consumption by 15-60-day-old animals.

\section{References}

BORDERAS, T. F.; PASSILLÉ, A. M. B.; RUSHEN, J. Feeding behavior of calves fed small or large amounts of milk. Journal of Dairy Science, Champaign, v. 92, n. 6, p. 2843-2852, 2009.

CARVALHO, P. A.; SANCHES, L. M. B.; VIÉGAS, J.; VELHO, J. P.; JAURI, G. C.; RODRIGUES, M. B. Desenvolvimento de estômago de bezerros holandeses desaleitados precocemente. Revista Brasileira de Zootecnia, Viçosa, MG, v. 32, n. 6, p. 1461-1468, 2003.

CHURCH, D. C. Alimentos y alimentacion del ganado. Montevideo: Editorial Hemisferio Sur, 1984. 789 p.

CUNHA, D. N. F. V.; MARTUSCELLO, J. A. Criação de bezerras de rebanhos leiteiros em fase de aleitamento. In: SILVA, J. C. P. M.; OLIVEIRA, A. S.; VELOSO, C. M. (Ed.). Manejo e administração em bovinocultura leiteira. Viçosa, MG: Suprema, 2009, p. 29-54.

FERREIRA, G. A.; ZIECH, R. E.; GUIRRO, E. C. B. P. Bem-estar de bovinos leiteiros: revisão de literatura. Revista Veterinária em Foco, Palotina, v. 10, n. 2, p. 195209, 2013.

FUJIWARA, M.; RUSHEN, J.; PASSILLÉ, A. M. Dairy calves' adaptation to group housing with automated feeders. Applied Animal Behaviour Science, Agassiz, v. 158, n. 1, p. 1-7, 2014.

HEINRICHS, A. J.; HARGROVE, G. L. Standards of weight and height for Holstein heifers. Journal of Dairy Science, Champaign, v. 70, n. 3, p. 653-660, 1987. 
HEPOLA, H. Milk feeding systems for dairy calves in groups: effects on feed intake, growth and health. Applied Animal Behaviour Science, Vancouver, v. 80, n. 3, p. 233-243, 2003.

INSTITUTO BRASILEIRO DE GEOGRAFIA E ESTATÍSTICA - IBGE. Indicadores agropecuários. Editora: Cidade, 2015. Disponível em: <http://www. ibge.gov.br/home/estatistica/economia/ppm/2014/ default_xls_brasil.shtm>. Acesso em: 16 set. 2016.

JASPER, J.; WEARY, D. M. Effects of ad libitum milk intake on dairy calves. Journal of Dairy Science, Champaign, v. 85, n. 11, p. 3054-3058, 2002.

JENSEN, M. B. Computer-controlled milk feeding of group-housed calves: the effect of milk allowance and weaning type. Journal of Dairy Science, Champaign, v. 89, n. 1, p. 201-206, 2006.

KHAN, M. A.; LEE, H. J.; KIM, H. S.; KI, K. S.; HUR, T. Y.; SUH, G. H.; KANG, S. J.; CHOI, Y. J. Structural growth, rumen development, and metabolic and immune responses of Holstein male calves fed milk through step-down and conventional methods. Journal of Dairy Science, Champaign, v. 90, n. 7, p. 3376-3387, 2007.

OLIVEIRA, C. E. A.; BRANDO, P. T. V. M.; CARNEIRO FILHO, A. J.; BORGES, C. G.; OLIVEIRA, J. A.; MINGOTE, L. C. Criação e desenvolvimento de bezerras leiteiras no periodo de aleitamento: práticas de manejo. Araxá: ISAH, 2014. 9 p.

OLIVEIRA, M. V. M.; FIGUERÓ, R.; BARBOSA, C. S.; LUZ, D. F.; SIMÕES, A. R. Criação de bezerras leiteiras durante a fase de aleitamento. Dourados: UEMS, 2009. $80 \mathrm{p}$.

OVERTON, M. W.; CORBETT, R. B.; BOOMER, W. B. A economic comparison of conventional vs. Intensive heifer reaning. In: WESTERN DAIRY MANAGEMENT CONFERENCE, 2013, Reno. Proceedings... Reno: [s.n.], 2013. p. 123-131.

PASSILLÉ, A. M.; BORDERAS, T. F.; RUSHEN, J. Weaning age of calves fed a high milk allowance by automated feeders: effects on feed, water, and energy intake, behavioral signs of hunger, and weight gains. Journal of Dairy Science, Champaign, v. 94, n. 3, p. 1401-1408, 2011.

RAETH-KNIGHT, M.; CHESTERJONES, H.; HAYES, S.; LINN, J.; LARSON, R.; ZIEGLER, D.; ZIEGLER, B.; BROADWATER, N. Impact of conventional or intensive milk replacer programs on Holstein heifer performance through six months of age and during first lactation. Journal of Dairy Science, Champaign, v. 92, n. 2, p. 799-809, 2009.
REIS, G. M.; ALBUQUERQUE, F. H. M. R.; TEODORO, R. L.; FERREIRA, M. B.; MARTINS, G. A.; MONTEIRO, J. B. N.; VALENTE, B. D.; FRIDRICH, A. B.; MADALENA, F. E. Estimativa do peso vivo de novilhas mestiças leiteiras a partir de medidas corporais. In: SIMPÓSIO DA SOCIEDADE BRASILEIRA DE MELHORAMENTO GENÉTICO, 5., 2004, Pirassununga. Anais... Pirassununga: Sociedade Brasileira de Melhoramento Animal, 2004. p. 1-3.

SANTOS, G. T.; DAMASCENO, J. C.; KAZAMA, D. C. Criação e manejo de bezerras leiteiras. In: SANTOS, G. T.; MASSUDA, E. M.; KAZAMA, D. C. S.; JOBIM, C. C.; BRANCO, A. F. (Org.). Bovinocultura leiteira: bases zootécnicas, fisiológicas e de produção. Maringá: Eduem, 2010. p. 47-78

STATISTICAL ANALYSIS SYSTEM - SAS. SAS OnlineDoc ${ }^{\circledR}$ 9.2. Cary: SAS Institute, 2010.

SVENSSON, C.; LIBERG, P. The effect of group size on health and growth rate of Swedish dairy calves housed in pens with automatic milk-feeders. Preventive Veterinary Medicine, Colorado, v. 73, n. 1, p. 43-53, 2006.

TAPKI, I. Effects of individual or combined housing systems on behavioural and growth responses of dairy calves. Acta Agriculturae Scandinavica, Section A, Turkey, v. 57, n. 1, p. 55-60, 2007.

VAN AMBURGH, M. A systemic approach to calf and heifer rearing: "Intensified" feeding and the target growth system. In: WESTERN DAIRY MANAGEMENT CONFERENCE, 6., 2003, Reno. Proceedings... Reno, 2003. p. 59-68.

VIÉGAS, J. Manejo de novilhas leiteiras, em busca da eficiência técnica. In: SANTOS, G. T.; MASSUDA, E. M.; KAZAMA, D. C. S.; JOBIM, C. C.; BRANCO, A. F. (Org.). Bovinocultura leiteira: bases zootécnicas, fisiológicas e de produção. Maringá: Eduem, 2010. p. 79108.

VIEIRA, A. P.; PASSILLÉ, A. M.; WEARY, D. M. Effects of the early social environment on behavioral responses of dairy calves to novelevents. Journal of Dairy Science, Champaign, v. 95, n. 9, p. 5149-5155, 2012.

VIEIRA, A. P.; von KEYSERLINGK, M. A. G.; WEARY, D. M. Effects of pair versus single housing on performance and behavior of dairy calves before and after weaning from milk. Journal of Dairy Science, Champaign, v. 93, n. 7, p. 3079-3085, 2010.

VON KEYSERLINGK, M. A. G.; WEARY, D. M. Desafios e oportunidades no manejo de animais jovens. [S.1.: s.n.], 2012. Disponível em: $<$ https://www. researchgate.net/publication/266006786_Desafios e_oportunidades_no_manejo_de_animais_jovens $>$. Acesso em: ago de 2016. 
